\title{
KAPASITAS SALURAN PHB BGR KELAPA GADING JAKARTA UTARA DENGAN MENGGUNAKAN METODE HEC-RAS
}

\author{
Mohammad Imamuddin ${ }^{1}$ dan Rismala Mufti Farhanah ${ }^{2}$
}

1Prodi Teknik Sipil, Universitas Muhammadiyah Jakarta, Jl. Cempaka Putih Tengah 27, Jakarta, 10510

Email korespondensi: imamuddin0002@gmail.com

2Prodi Teknik Sipil, Universitas Muhammadiyah Jakarta, Jl. Cempaka Putih Tengah 27, Jakarta, 10510

Email: mufti.sipil@gmail.com

\begin{abstract}
ABSTRAK
Saluran PHB BGR Gading Kirana terletak di Jalan Raya Gading Kirana pada koordinat $6^{\circ} 08^{\prime} 37,9^{\prime \prime}-6^{\circ} 10^{\prime} 14,2^{\prime \prime}$ Lintang Selatan, 106 $54^{\prime} 09,6^{\prime \prime}-106^{\circ} 53^{\prime} 16,2^{\prime \prime}$ Bujur Timur. Di daerah sekitar Saluran PHB BGR Gading Kirana masih sering terjadi banjir setiap kali musim hujan tiba karena jarak antar tali-tali air yang terbilang berjauhan, menyebabkan surutnya genangan air menjadi lambat serta terkadang saluran tali air mengalami penyumbatan, inilah yang menyebabkan banjir ketika air pada saluran di bawah trotoar tidak cukup mampu menampung volume air yang masuk. Dari kondisi diatas, maka perlu dilakukan analisis permasalahan banjir di daerah Saluran PHB BGR Gading Kirana untuk mengetahui apakah Saluran PHB BGR Gading Kirana masih dapat menampung debit air berdasarkan curah hujan 25 tahun terakhir dan apakah Saluran PHB BGR Gading Kirana perlu normalisasi. Berdasarkan hasil perhitungan manual dan aplikasi HEC-RAS, Saluran PHB BGR Gading Kirana tidak dapat menampung debit air berdasarkan curah hujan 25 tahun terakhir sebesar 46,95 m³ $/$ det. Pada titik 0 - titik 33 perlu dilakukan normalisasi dengan cara penambahan turap dari $4 \mathrm{~m}$ menjadi 5,5 m.
\end{abstract}

Kata kunci: Saluran PHB BGR Gading Kirana, Banjir, HEC-RAS

\begin{abstract}
Canal PHB BGR Gading Kirana is located on Gading Kirana Highway at coordinates $6^{\circ} 08^{\prime} 37,9^{\prime \prime}-$ $6^{\circ} 10^{\prime} 14,2^{\prime \prime}$ South Latitude, 106 54'09, $6^{\prime \prime}-106^{\circ} 53^{\prime} 16,2^{\prime \prime}$ East. In the area around the Saluran PHB $B G R$ Gading Kirana, there are still frequent flooding every time the rainy season comes because the distance between the ropes of water that is fairly far apart, causing reflux puddle of water becomes slow and sometimes the canal strap water blockag, this is what caused the flood when the water in the channel under the pavement is not enough to accommodate the volume of incoming water. From the above conditions, it is necessary to do the analysis of the flood problem in the area of the Tract PHB BGR Gading Kirana to determine whether the Canal PHB BGR Gading Kirana can still accommodate the flow of water based on the rainfall of the last 25 years and is the PHB BGR Gading Kirana need to be normalized. Based on the results of manual calculation and application of HECRAS, Channel PHB BGR Gading Kirana cannot accommodate the flow of water based on the rainfall of the last 25 years by $46,95 \mathrm{~m}^{3} / \mathrm{sec}$. At the point of 0 - point 33 needs to be normalized by means of the addition of plaster from $4 \mathrm{~m}$ to $5.5 \mathrm{~m}$. Abstract starts with the word
\end{abstract}

Keywords: Canal PHB BGR Gading Kirana, Flood, HEC-RAS 


\section{PENDAHULUAN}

Di daerah sekitar Saluran PHB BGR Gading Kirana, masih sering terjadi banjir setiap kali musim hujan tiba. Banjir merupakan permasalahan yang kerap terjadi di lingkungan masyarakat setempat. Salah satu faktor yang menyebabkan sering terjadi banjir adalah karena jarak antar tali-tali air yang terbilang berjauhan, menyebabkan surutnya genangan air menjadi lambat. Jarak antar tali-tali air yaitu 9 meter. Terkadang saluran tali air mengalami penyumbatan, inilah yang menyebabkan banjir ketika air pada saluran di bawah trotoar tidak cukup mampu menampung volume air yang masuk. Faktor lain yang menyebabkan sering terjadi banjir yaitu debit saluran yang lebih rendah daripada debit rencana sehingga air dari Saluran PHB BGR ketika hujan tidak dapat mengalir secara gravitasi atau secara alami ke Kali Sunter (Tribun Jakarta, 30 Januari 2019).

Dari kondisi di atas, maka perlu dilakukan analisis permasalahan banjir di daerah Saluran PHB BGR Gading Kirana yang diharapkan dapat menjadi masukan untuk pemerintah agar dapat menangani dengan segera permasalahan banjir yang sering terjadi.

Tujuan dari analisis ini adalah:

1. Mengetahui debit rancangan saluran drainase eksisting pada lokasi.

2. Mengetahui apakah kapasitas saluran drainase eksisting yang berada di lokasi studi dapat menampung debit rancangan kala ulang 25 tahun atau tidak.

3. Mendapatkan kapasitas yang mampu menampung debit banjir dengan periode kala ulang 25 tahun.

4. Mengetahui kapasitas pompa yang dibutuhkan.

\section{LANDASAN TEORI}

\section{DAS}

Daerah Aliran Sungai (DAS) adalah suatu wilayah daratan yang merupakan satu kesatuan dengan sungai dan anak-anak sungainya yang berfungsi menampung, menyimpan dan mengalirkan air. DAS dalam skala kecil disebut catchment area yang merupakan suatu wilayah daratan yang dibatasi oleh punggung bukit atau batasbatas pemisah topografi. yang berfungsi menerima, menyimpan dan mengalirkan curah hujan yang jatuh di atasnya

\section{Banjir dan genangan}

Banjir dan genangan adalah suatu kondisi dimana tidak tertampungnya air dalam saluran pembuang atau terhambatnya aliran air di dalam saluran pembuang, sehingga meluap menggenangi daerah di sekitarnya.

\section{Sistem drainase}

Drainase yang berasal dari Bahasa Inggris drainage mempunyai arti mengalirkan, menguras, membuang, atau mengalihkan air. Drainase secara umum dapat didefinisikan sebagai suatu tindakan teknis untuk mengurangi kelebihan air, baik yang berasal dari air hujan, rembesan, maupun kelebihan air irigasi dari suatu kawasan/lahan, sehingga fungsi kawasan/lahan tidak terganggu. Drainase dapat juga diartikan sebagai usaha untuk mengontrol kualitas air tanah dalam kaitannya dengan salinitas. Jadi, drainase menyangkut tidak hanya air permukaan tapi juga air tanah.

\section{Desain hidrologi periode ulang ( $\mathrm{T}$ )}

Tabel 1. Kriteria Desain Hidrologi Sistem Drainase Perkotaan

\begin{tabular}{|c|c|c|c|c|}
\hline \multirow{2}{*}{$\begin{array}{l}\text { Tipologi } \\
\text { Kota }\end{array}$} & \multicolumn{4}{|c|}{ Catchment Area (Ha) } \\
\hline & $<10$ & $\begin{array}{l}10- \\
100\end{array}$ & $\begin{array}{l}101- \\
500\end{array}$ & $>500$ \\
\hline $\begin{array}{l}\text { Kota } \\
\text { Metropolitan }\end{array}$ & 2 th & $\begin{array}{l}2 \\
\text { th- } \\
5 \text { th }\end{array}$ & $\begin{array}{l}5 \text { th- } \\
10 \text { th }\end{array}$ & 5 th-10 th \\
\hline Kota Besar & 2 th & $\begin{array}{l}2 \\
\text { th- } \\
5 \text { th }\end{array}$ & $\begin{array}{l}2 \text { th- } 5 \\
\text { th }\end{array}$ & 5 th-10 th \\
\hline Kota Sedang & 2 th & $\begin{array}{l}2 \\
\text { th- } \\
5 \text { th }\end{array}$ & $\begin{array}{l}2 \text { th- } 5 \\
\text { th }\end{array}$ & 5 th-10 th \\
\hline
\end{tabular}




\begin{tabular}{ccccc}
\hline Tipologi & \multicolumn{4}{c}{ Catchment Area (Ha) } \\
\cline { 2 - 5 } Kota & $<10$ & $\mathbf{1 0}-$ & $\mathbf{1 0 1 -}$ & $>\mathbf{5 0 0}$ \\
& & $\mathbf{1 0 0}$ & $\mathbf{5 0 0}$ & \\
\hline Kota Kecil & 2 th & 2 th & 2 th & 2 th \\
\hline
\end{tabular}

Sumber: Permen. PU No. 12 Tentang Penyelenggaraan Sistem Drainase Perkotaan Tahun 2014

\section{Distribusi probabilitas}

a. Nilai rata-rata

$$
\overline{\mathrm{X}}=\sum_{\mathrm{i}=1}^{\mathrm{n}} \mathrm{Xi} / \mathrm{n}
$$

Dengan $\bar{X}=$ nilai rata-rata, $\mathrm{Xi}=$ nilai varian, $\mathrm{n}=$ jumlah data.

b. Standar deviasi

$$
\mathrm{S}_{\mathrm{x}}=\sqrt{\frac{\sum_{\mathrm{i}=1}^{\mathrm{n}}(\mathrm{Xi}-\overline{\mathrm{X}})^{2}}{\mathrm{n}-1}}
$$

Dengan $\mathrm{S}_{\mathrm{x}}=$ standar deviasi, $\overline{\mathrm{X}}=$ nilai rata-rata, $\mathrm{Xi}=$ nilai varian, $\mathrm{n}=$ jumlah data.

c. Koefisien variasi

$$
\mathrm{C}_{\mathrm{v}}=\frac{\mathrm{S}_{\mathrm{x}}}{\overline{\mathrm{X}}}
$$

Dengan $\mathrm{C}_{\mathrm{v}}=$ koefisien variasi, $\mathrm{S}_{\mathrm{x}}=$ standar deviasi, $\overline{\mathrm{X}}=$ nilai rata-rata.

d. Koefisien kemiringan

$$
\mathrm{C}_{\mathrm{s}}=\frac{\mathrm{n} \times \sum_{\mathrm{i}=1}^{\mathrm{n}}(\mathrm{Xi}-\overline{\mathrm{X}})^{3}}{(\mathrm{n}-1) \times(\mathrm{n}-2) \times \mathrm{S}_{\mathrm{x}}{ }^{3}}
$$

Dengan $\quad \mathrm{C}_{\mathrm{s}}=$ koefisien kemiringan/skewness, $\mathrm{S}_{\mathrm{x}}=$ standar deviasi, $\mathrm{n}=$ jumlah data.

\section{Jenis distribusi data}

Tabel 2. Persyaratan Parameter Statistik Suatu Distribusi

\begin{tabular}{lll}
\hline No & Distribusi & Satuan \\
\hline 1 & Gumbel & $\mathrm{C}_{\mathrm{s}}=1,14$ \\
& & $\mathrm{C}_{\mathrm{k}}=5,4$ \\
\hline 2 & Normal & $\mathrm{C}_{\mathrm{s}}=0$ \\
& & $\mathrm{C}_{\mathrm{k}}=3$ \\
\hline 3 & Log Normal & $\mathrm{C}_{\mathrm{s}}=\mathrm{C}_{\mathrm{v}}{ }^{3}+3 \mathrm{C}_{\mathrm{v}}$ \\
& & $\mathrm{C}_{\mathrm{k}}=\mathrm{C}_{\mathrm{v}}{ }^{8}+6 \mathrm{C}_{\mathrm{v}}{ }^{6}+$ \\
& & $15 \mathrm{C}_{\mathrm{v}}{ }^{4}+16 \mathrm{C}_{\mathrm{v}}{ }^{2}+3$ \\
\hline 4 & Log Pearson III & $\begin{array}{l}\text { Selain dari nilai } \\
\text { di atas }\end{array}$ \\
\hline
\end{tabular}

Sumber: Bambang, T (2008) a. Metode gumbel

$$
X_{t}=\bar{X} \frac{\left(Y_{t}-Y_{n}\right)}{S_{n}} \cdot S_{X}
$$

Dengan $X_{\mathrm{t}}=$ curah hujan rencana $(\mathrm{mm})$, $\mathrm{Y}_{\mathrm{t}}=$ reduced variate parameter Gumbel, $\mathrm{Y}_{\mathrm{n}}=$ reduced mean.

b. Metode distribusi Log Pearson III

$$
\log X_{t}=\log \bar{X}+K_{t} \cdot S_{x}
$$

Dengan $\log X_{t}=$ curah hujan rencana $(\mathrm{mm}), \log \bar{X}=$ curah hujan nilai ratarata $(\mathrm{mm}), \mathrm{K}_{\mathrm{t}}=$ faktor frekuensi (Log Pearson III), $\mathrm{S}_{\mathrm{x}}=$ standar deviasi.

\section{Debit saluran rencana ( $\mathbf{Q}_{\text {hidrologi }}$ )}

a. Metode rasional

$$
\mathrm{Q}=0,278 \text {.C . I . A }
$$

Dengan $Q=$ debit banjir $\left(\mathrm{m}^{3} / \mathrm{det}\right), \mathrm{C}=$ koefisien run off, $\mathrm{I}=$ intensitas curah hujan (mm/jam), $\mathrm{A}=$ luas catchment area $\left(\mathrm{km}^{2}\right)$.

b. Koefisien run off

$$
\mathrm{C}_{\text {rata-rata }}=\frac{\sum_{i=1}^{n} \mathrm{C}_{\mathrm{i}} \mathrm{A}_{\mathrm{i}}}{\sum_{i=1}^{n} \mathrm{~A}_{\mathrm{i}}}
$$

Dengan $\mathrm{C}=$ nilai koefisien run off, $\mathrm{A}=$ luas catchment area $\left(\mathrm{km}^{2}\right)$.

c. Waktu konsentrasi

$$
\mathrm{T}_{\mathrm{c}}=\frac{0,0195 \cdot \mathrm{L}^{0,77}}{\mathrm{~S}^{0,385}}
$$

Dengan $\mathrm{T}_{\mathrm{c}}=$ waktu konsentrasi (menit), $\mathrm{L}=$ Panjang lintasan air $(\mathrm{m}), \mathrm{S}=$ kemiringan saluran.

d. Waktu konsentrasi

$$
\mathrm{I}=\frac{\mathrm{R}_{34}}{24}\left[\frac{24}{\mathrm{~T}_{\mathrm{c}}}\right]^{2 / 3}
$$

Dengan $\mathrm{R}_{24}=$ curah hujan dalam 24 jam $(\mathrm{mm}), \mathrm{T}_{\mathrm{c}}=$ waktu konsentrasi (jam), I = intensitas curah hujan ( $\mathrm{mm} / \mathrm{jam})$.

\section{Debit saluran eksisting ( $\mathbf{Q}_{\text {hidrolika }}$ )}

a. Debit saluran

$$
\mathrm{Q}=\mathrm{A} \cdot \mathrm{V}
$$

Dengan $Q=$ debit aliran $\left(\mathrm{m}^{3} / \mathrm{det}\right), \mathrm{A}=$ luas penampang basah $(\mathrm{m}), \mathrm{V}=$ kecepatan aliran rata-rata (m/det).

b. Kecepatan aliran 


$$
\mathrm{V}=\frac{1}{\overline{\mathrm{n}}} \cdot \mathrm{R}^{2 / 3} \cdot \mathrm{S}^{1 / 2}
$$

Dengan $\mathrm{V}=$ kecepatan aliran rata-rata ( $\mathrm{m} /$ det $), \quad \mathrm{n}=$ koefisien kekasaran Manning, $\mathrm{R}=$ jari-jari hidrolis (m), $\mathrm{S}=$ kemiringan saluran.

c. Intensitas hujan

$$
I=\frac{R_{34}}{24}\left[\frac{24}{T_{c}}\right]^{2 / 3}
$$

Dengan $\mathrm{R}_{24}=$ curah hujan dalam 24 jam $(\mathrm{mm}), \mathrm{T}_{\mathrm{c}}=$ waktu konsentrasi (jam), $\mathrm{I}=$ intensitas curah hujan (mm/jam).

\section{Program HEC-RAS}

Hydrologic Engineering Center - River Analysis System (HEC-RAS) merupakan program aplikasi untuk memodelkan aliran sungai yang dibuat oleh Hydrologic Engineering Center (HEC) yang merupakan satu divisi dalam Institute for Water Resources (IWR) di bawah US Army Corps of Engineers (USACE). Dalam aplikasi HEC-RAS terdapat empat komponen utama yaitu sebagai berikut:

a. Profil permukaan air aliran permanen (steady flow water surface profiles)

Modul ini berfungsi untuk menghitung profil permukaan air untuk aliran permanen berubah beraturan (steady gradually varied flow). Program mampu memodelkan jaringan sungai, sungai dendritik, maupun sungai tunggal.

b. Simulasi aliran tak permanen (unsteady flow simulation)

Modul ini mampu simulasikan aliran tak permanen satu dimensi pada sungai yang memiliki alur kompleks.

c. Hitungan transpor sedimen (sediment transport)

Modul ini mampu simulasikan transpor sedimen satu dimensi (simulasi perubahan dasar sungai) akibat gerusan atau deposisi dalam waktu yang cukup panjang (umumnya tahunan), namun dapat pula dilakukan simulasi perubahan dasar sungai akibat sejumlah banjir besar.

d. Analisis kualitas air
Modul ini dapat dipakai untuk melakukan analisis kualitas air di sungai. HEC-RAS dapat dipaki untuk melakukan analisis temperatur air serta simulasi transpor seperti: Algae, kadar oksigen, kadar nitrogen dan sebagainya.

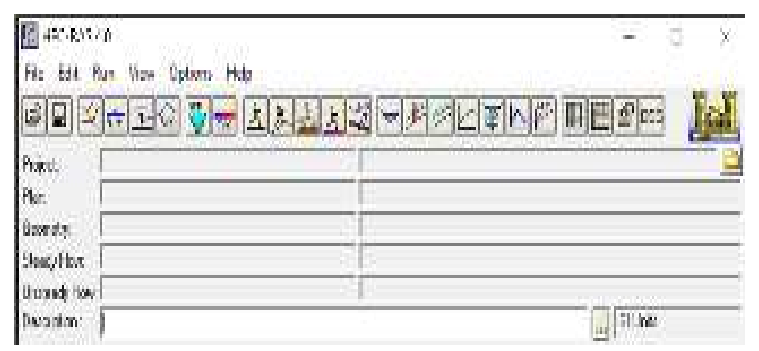

Gambar 1. Tampilan Program HEC-RAS

\section{HASIL DAN PEMBAHASAN}

\section{Desain hidrologi periode ulang ( $T$ )}

Saluran PHB BGR berdasarkan Tabel 1 dengan luas $>220$ Ha menggunakan periode ulang (T) 25 tahun.

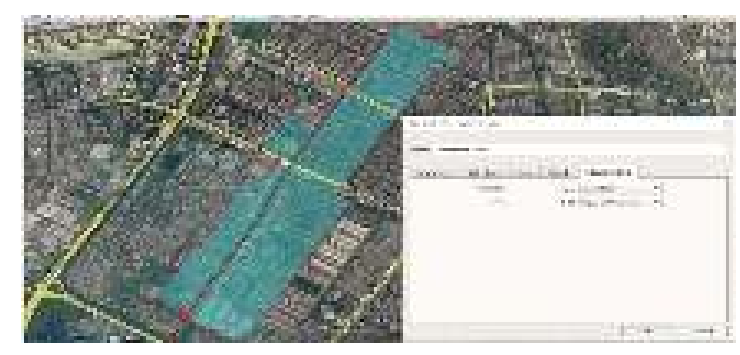

Gambar 2. Luas Catchment Area

\section{Distribusi probabilitas}

a. Curah hujan maksimum

Tabel 3. Curah Hujan Maksimum

\begin{tabular}{ccc}
\hline No & Tahun & $\begin{array}{c}\text { Curah } \\
\text { Hujan } \\
\text { Max }\end{array}$ \\
\hline 1 & 1996 & 216.2 \\
\hline 2 & 1997 & 125.6 \\
\hline 3 & 1998 & 162.2 \\
\hline 4 & 1999 & 147.2 \\
\hline 5 & 2000 & 94.8 \\
\hline 6 & 2001 & 82.2 \\
\hline
\end{tabular}




\begin{tabular}{ccc}
\hline No & Tahun & $\begin{array}{c}\text { Curah } \\
\text { Hujan } \\
\text { Max }\end{array}$ \\
\hline 7 & 2002 & 168.5 \\
\hline 8 & 2003 & 199.7 \\
\hline 9 & 2004 & 129.3 \\
\hline 10 & 2005 & 124.1 \\
\hline 11 & 2006 & 72 \\
\hline 12 & 2007 & 234.7 \\
\hline 13 & 2008 & 192.7 \\
\hline 14 & 2009 & 122.5 \\
\hline 15 & 2010 & 93 \\
\hline 16 & 2011 & 119.2 \\
\hline 17 & 2012 & 105.2 \\
\hline 18 & 2013 & 193.4 \\
\hline 19 & 2014 & 147.9 \\
\hline 20 & 2015 & 277.5 \\
\hline 21 & 2016 & 124.5 \\
\hline 22 & 2017 & 179.7 \\
\hline 23 & 2018 & 104.6 \\
\hline 24 & 2019 & 90.5 \\
\hline 25 & 2020 & 277.5 \\
\hline
\end{tabular}

Sumber: BMKG Kemayoran

Tabel 4. Perhitungan Distribusi Curah Hujan

\begin{tabular}{|c|c|c|c|c|c|}
\hline Tahun & $X i$ & $X i-X$ & $\begin{array}{l}(X i- \\
X)^{2}\end{array}$ & $\begin{array}{l}(X i- \\
X)^{3}\end{array}$ & $\begin{array}{l}(X i- \\
X)^{4}\end{array}$ \\
\hline \multirow[t]{3}{*}{1996} & 216.2 & 65 & 4201 & & $\begin{array}{l}176 \\
450\end{array}$ \\
\hline & & & & 2722 & 01.2 \\
\hline & & & & 49 & \\
\hline \multirow[t]{3}{*}{1997} & 125.6 & -26 & 665 & & 442 \\
\hline & & & & 1715 & 252. \\
\hline & & & & 0 & 86 \\
\hline \multirow[t]{3}{*}{1998} & 162.2 & 11 & 117 & & 136 \\
\hline & & & & & 65.4 \\
\hline & & & & 1264 & 6 \\
\hline \multirow[t]{2}{*}{1999} & 147.2 & -4 & 18 & & 307. \\
\hline & & & & -73 & 63 \\
\hline \multirow[t]{3}{*}{2000} & 94.8 & -57 & 3202 & - & \\
\hline & & & & 1812 & 102 \\
\hline & & & & 06 & 540 \\
\hline
\end{tabular}

\begin{tabular}{|c|c|c|c|c|c|}
\hline Tahun & $X i$ & $X i-X$ & $\begin{array}{l}(X i- \\
X)^{2}\end{array}$ & $\begin{array}{l}(X i- \\
X)^{3}\end{array}$ & $\begin{array}{l}(X i- \\
X)^{4}\end{array}$ \\
\hline & & & & & $\begin{array}{l}96.0 \\
1\end{array}$ \\
\hline \multirow[t]{4}{*}{2001} & 82.2 & -69 & 4787 & & 229 \\
\hline & & & & - & 151 \\
\hline & & & & 3312 & 71.2 \\
\hline & & & & 02 & 4 \\
\hline \multirow[t]{3}{*}{2002} & 168.5 & 17 & 293 & & 857 \\
\hline & & & & & 43.8 \\
\hline & & & & 5011 & 7 \\
\hline \multirow[t]{3}{*}{2003} & 199.7 & 48 & 2334 & & 544 \\
\hline & & & & 1127 & 778 \\
\hline & & & & 63 & 6.34 \\
\hline \multirow[t]{3}{*}{2004} & 129.3 & -22 & 488 & & 238 \\
\hline & & & & 1077 & 026. \\
\hline & & & & 6 & 64 \\
\hline \multirow[t]{3}{*}{2005} & 124.1 & -27 & 745 & - & 554 \\
\hline & & & & 2032 & 481. \\
\hline & & & & 0 & 20 \\
\hline \multirow[t]{4}{*}{2006} & 72 & -79 & 6302 & & 397 \\
\hline & & & & & 209 \\
\hline & & & & 5003 & 33.2 \\
\hline & & & & & 8 \\
\hline \multirow[t]{4}{*}{2007} & 234.7 & 83 & 6941 & & 481 \\
\hline & & & & & 759 \\
\hline & & & & 5782 & 44.8 \\
\hline & & & & 59 & 9 \\
\hline \multirow[t]{3}{*}{2008} & 192.7 & 41 & 1707 & & 291 \\
\hline & & & & 7050 & 276 \\
\hline & & & & 6 & 1.21 \\
\hline \multirow[t]{3}{*}{2009} & 122.5 & -29 & 835 & - & 696 \\
\hline & & & & 2410 & 417. \\
\hline & & & & 8 & 86 \\
\hline \multirow[t]{4}{*}{2010} & 93 & -58 & 3409 & & 116 \\
\hline & & & & & 223 \\
\hline & & & & 1990 & 61.9 \\
\hline & & & & 54 & 8 \\
\hline \multirow[t]{3}{*}{2011} & 119.2 & -32 & 1036 & & 107 \\
\hline & & & & 3334 & 343 \\
\hline & & & & 9 & 5.54 \\
\hline \multirow[t]{3}{*}{2012} & 105.2 & -46 & 2133 & - & 455 \\
\hline & & & & 9853 & 110 \\
\hline & & & & 4 & 2.62 \\
\hline \multirow[t]{3}{*}{2013} & 193.4 & 42 & 1765 & & 311 \\
\hline & & & & 7415 & 525 \\
\hline & & & & 2 & 3.75 \\
\hline \multirow[t]{2}{*}{2014} & 147.9 & -3 & 12 & & 148. \\
\hline & & & & -42 & 02 \\
\hline
\end{tabular}




\begin{tabular}{|c|c|c|c|c|c|}
\hline Tahun & $X i$ & $X \boldsymbol{i}-\boldsymbol{X}$ & $\begin{array}{l}(X i- \\
X)^{2}\end{array}$ & $\begin{array}{l}(X i- \\
X)^{3}\end{array}$ & $\begin{array}{l}(X i- \\
X)^{4}\end{array}$ \\
\hline 2015 & 277.5 & 126 & $\begin{array}{l}1590 \\
4\end{array}$ & $\begin{array}{l}2005 \\
715\end{array}$ & $\begin{array}{l}252 \\
944 \\
740 \\
05\end{array}$ \\
\hline 2016 & 124.5 & -27 & 723 & $\begin{array}{l}- \\
1943 \\
9\end{array}$ & $\begin{array}{l}522 \\
677 \\
73\end{array}$ \\
\hline 2017 & 179.7 & 28 & 802 & $\begin{array}{l}2269 \\
4\end{array}$ & $\begin{array}{l}642 \\
513 \\
41\end{array}$ \\
\hline 2018 & 104.6 & -47 & 2189 & $\begin{array}{l}- \\
1024 \\
24\end{array}$ & $\begin{array}{l}479 \\
223 \\
2.99\end{array}$ \\
\hline 2019 & 90.5 & -61 & 3707 & $\begin{array}{l}- \\
2257 \\
33\end{array}$ & $\begin{array}{l}137 \\
444 \\
33.2 \\
3\end{array}$ \\
\hline 2020 & 277.5 & 126 & $\begin{array}{l}1590 \\
4\end{array}$ & $\begin{array}{l}2005 \\
715\end{array}$ & $\begin{array}{l}252 \\
944 \\
740 \\
05\end{array}$ \\
\hline Total & $\begin{array}{l}3784 . \\
7\end{array}$ & $\begin{array}{l}4.831 \\
69 E- \\
13\end{array}$ & $\begin{array}{l}8021 \\
8.366 \\
4\end{array}$ & $\begin{array}{l}3384 \\
578.2 \\
06\end{array}$ & $\begin{array}{l}695 \\
056 \\
229 \\
1\end{array}$ \\
\hline
\end{tabular}

- $\quad$ Nilai rata-rata $(\overline{\mathrm{X}})$

$$
\begin{aligned}
\bar{X} & =\sum_{\mathrm{i}=1}^{\mathrm{n}} \mathrm{Xi} / \mathrm{n} \\
& =\frac{3,784.7}{25}=151.39
\end{aligned}
$$

- $\quad$ Standar deviasi $\left(\mathrm{S}_{\mathrm{x}}\right)$

Untuk mencari standar deviasi $\left(\mathrm{S}_{\mathrm{x}}\right)$ digunakan rumus sebagai berikut:

$$
\begin{aligned}
S_{\mathrm{X}} & =\sqrt{\frac{\sum_{\mathrm{i}=1}^{\mathrm{n}(\mathrm{Xi}-\overline{\mathrm{X}})^{2}}}{\mathrm{n}-1}} \\
& =\sqrt{\frac{80,218.37}{24}}=57.81
\end{aligned}
$$

- Koefisien variasi $\left(C_{v}\right)$

$$
\begin{aligned}
C_{\mathrm{v}} & =\frac{S_{\mathrm{x}}}{\overline{\mathrm{X}}} \\
& =\frac{57.81}{151.39}=0.38
\end{aligned}
$$

- Koefisien kemiringan $\left(\mathrm{C}_{\mathrm{s}}\right)$

$$
\begin{aligned}
\mathrm{C}_{\mathrm{S}} & =\frac{\mathrm{n} \times \sum_{\mathrm{i}=1}^{\mathrm{n}}(\mathrm{Xi}-\overline{\mathrm{X}})^{3}}{(\mathrm{n}-1) \times(\mathrm{n}-2) \times \mathrm{S}_{\mathrm{x}}{ }^{3}} \\
& =\frac{25 \times 3384578.206}{24 \times 23 \times(57.81)^{3}}=0.79
\end{aligned}
$$

\begin{tabular}{|c|c|c|c|c|}
\hline No & Distribusi & Syarat & Hasil & \\
\hline \multirow[t]{2}{*}{1} & Gumbel & $\begin{array}{l}C_{s} \approx \\
1.1396\end{array}$ & $\begin{array}{l}\mathrm{C}_{\mathrm{s}} \\
0.79\end{array}$ & $=$ \\
\hline & & $\begin{array}{l}\mathrm{C}_{\mathrm{k}} \approx \\
5.4002\end{array}$ & $\begin{array}{l}\mathrm{C}_{\mathrm{k}} \\
3.20\end{array}$ & $=$ \\
\hline \multirow[t]{2}{*}{2} & Normal & $\begin{array}{l}C_{s}=0 \\
C_{k}=3\end{array}$ & $\begin{array}{l}C_{s} \\
0.79\end{array}$ & $=$ \\
\hline & & & $\begin{array}{l}\mathrm{C}_{\mathrm{k}} \\
3.20\end{array}$ & $=$ \\
\hline \multirow[t]{2}{*}{3} & $\begin{array}{l}\text { Log } \\
\text { Normal }\end{array}$ & $\begin{array}{l}\text { Cs } \approx 3 \\
\text { atau } 3 \mathrm{Cv}\end{array}$ & $\begin{array}{l}\mathrm{C}_{\mathrm{s}} \\
0.79\end{array}$ & $=$ \\
\hline & & & $\begin{array}{l}C_{v} \\
0.38\end{array}$ & $=$ \\
\hline \multirow[t]{2}{*}{4} & $\begin{array}{l}\text { Log } \\
\text { Pearson }\end{array}$ & $\begin{array}{l}\text { Tidak } \\
\text { memiliki }\end{array}$ & $\begin{array}{l}\mathrm{C}_{\mathrm{s}} \\
0.79\end{array}$ & $=$ \\
\hline & III & syarat & $\begin{array}{l}\mathrm{C}_{\mathrm{k}} \\
3.20\end{array}$ & $=$ \\
\hline
\end{tabular}

- Koefisien ketajaman $\left(C_{k}\right)$

$$
\begin{aligned}
\mathrm{C}_{\mathrm{k}} & =\frac{\mathrm{n}^{2} \times \sum_{\mathrm{i}=1}^{\mathrm{n}}(\mathrm{Xi}-\overline{\mathrm{X}})^{4}}{(\mathrm{n}-1) \times(\mathrm{n}-2) \times(\mathrm{n}-3) \times \mathrm{S}_{\mathrm{x}}{ }^{4}} \\
& =\frac{25^{2} \times 695056229.1}{24 \times 23 \times 22 \times(57.81)^{4}}=3.20
\end{aligned}
$$

- Jenis distribusi

\begin{tabular}{|c|c|c|c|c|c|}
\hline $\begin{array}{c}\text { Tah } \\
\text { un }\end{array}$ & $X i$ & $\begin{array}{c}\log \\
\boldsymbol{X i}\end{array}$ & $\begin{array}{c}\log \\
X i- \\
\log \\
X\end{array}$ & $\begin{array}{c}(\log X i \\
-\log \\
X)^{2}\end{array}$ & $\begin{array}{c}(\log \\
X i- \\
\log \\
X)^{3}\end{array}$ \\
\hline 199 & 216 & 2.334 & 0.1 & & 0.006 \\
\hline 6 & .2 & 9 & 840 & 0.0338 & 2 \\
\hline 199 & 125 & & - & & - \\
\hline \multirow[t]{2}{*}{7} & .6 & 2.099 & 0.0 & & 0.000 \\
\hline & & 0 & 519 & 0.0027 & 1 \\
\hline 199 & 162 & 2.210 & 0.0 & & 0.000 \\
\hline 8 & .2 & 1 & 592 & 0.0035 & 2 \\
\hline 199 & 147 & 2.167 & 0.0 & & 0.000 \\
\hline 9 & .2 & 9 & 170 & 0.0003 & 0 \\
\hline 200 & 94. & & - & & - \\
\hline \multirow[t]{2}{*}{0} & 8 & 1.976 & 0.1 & & 0.005 \\
\hline & & 8 & 741 & 0.0303 & 3 \\
\hline
\end{tabular}

Tabel 5. Perhitungan Distribusi Curah Hujan

Berdasarkan perhitungan dari analisis data curah hujan jenis distribusi yang memenuhi syarat yaitu distribusi Log Pearson III.

b. Metode Log Pearson III

Tabel 6. Distribusi Curah Hujan 


\begin{tabular}{|c|c|c|c|c|c|}
\hline $\begin{array}{c}\text { Tah } \\
\text { un }\end{array}$ & $X i$ & $\begin{array}{c}\log \\
X i\end{array}$ & $\begin{array}{c}\log \\
X i- \\
\log \\
X\end{array}$ & $\begin{array}{c}(\log X i \\
-\log \\
X)^{2}\end{array}$ & $\begin{array}{c}(\log \\
X i- \\
\log \\
X)^{3}\end{array}$ \\
\hline $\begin{array}{l}200 \\
1\end{array}$ & $\begin{array}{l}82 . \\
2\end{array}$ & $\begin{array}{l}1.914 \\
9\end{array}$ & $\begin{array}{l}- \\
0.2 \\
360\end{array}$ & 0.0557 & $\begin{array}{l}- \\
0.013 \\
1\end{array}$ \\
\hline $\begin{array}{l}200 \\
2\end{array}$ & $\begin{array}{l}168 \\
.5\end{array}$ & $\begin{array}{l}2.226 \\
6\end{array}$ & $\begin{array}{l}0.0 \\
757\end{array}$ & 0.0057 & $\begin{array}{l}0.000 \\
4\end{array}$ \\
\hline $\begin{array}{l}200 \\
3\end{array}$ & $\begin{array}{l}199 \\
.7\end{array}$ & $\begin{array}{l}2.300 \\
4\end{array}$ & $\begin{array}{l}0.1 \\
495\end{array}$ & 0.0223 & $\begin{array}{l}0.003 \\
3\end{array}$ \\
\hline $\begin{array}{l}200 \\
4\end{array}$ & $\begin{array}{l}129 \\
.3\end{array}$ & $\begin{array}{l}2.111 \\
6 \\
\end{array}$ & $\begin{array}{l}- \\
0.0 \\
393 \\
\end{array}$ & 0.0015 & $\begin{array}{l}- \\
0.000 \\
1\end{array}$ \\
\hline $\begin{array}{l}200 \\
5\end{array}$ & $\begin{array}{l}124 \\
.1\end{array}$ & $\begin{array}{l}2.093 \\
8\end{array}$ & $\begin{array}{l}- \\
0.0 \\
571\end{array}$ & 0.0033 & $\begin{array}{l}- \\
0.000 \\
2\end{array}$ \\
\hline $\begin{array}{l}200 \\
6\end{array}$ & 72 & $\begin{array}{l}1.857 \\
3 \\
\end{array}$ & $\begin{array}{l}- \\
0.2 \\
936 \\
\end{array}$ & 0.0862 & $\begin{array}{l}- \\
0.025 \\
3\end{array}$ \\
\hline $\begin{array}{l}200 \\
7 \\
\end{array}$ & $\begin{array}{l}234 \\
.7 \\
\end{array}$ & $\begin{array}{l}2.370 \\
5\end{array}$ & $\begin{array}{l}0.2 \\
196 \\
\end{array}$ & 0.0482 & $\begin{array}{l}0.010 \\
6 \\
\end{array}$ \\
\hline $\begin{array}{l}200 \\
8\end{array}$ & $\begin{array}{l}192 \\
.7\end{array}$ & $\begin{array}{l}2.284 \\
9\end{array}$ & $\begin{array}{l}0.1 \\
340\end{array}$ & 0.0180 & $\begin{array}{l}0.002 \\
4\end{array}$ \\
\hline $\begin{array}{l}200 \\
9\end{array}$ & $\begin{array}{l}122 \\
.5\end{array}$ & $\begin{array}{l}2.088 \\
1 \\
\end{array}$ & $\begin{array}{l}- \\
0.0 \\
628 \\
\end{array}$ & 0.0039 & $\begin{array}{l}- \\
0.000 \\
2\end{array}$ \\
\hline $\begin{array}{l}201 \\
0\end{array}$ & 93 & $\begin{array}{l}1.968 \\
5\end{array}$ & $\begin{array}{l}- \\
0.1 \\
824\end{array}$ & 0.0333 & $\begin{array}{l}- \\
0.006 \\
1\end{array}$ \\
\hline $\begin{array}{l}201 \\
1\end{array}$ & $\begin{array}{l}119 \\
.2\end{array}$ & $\begin{array}{l}2.076 \\
3\end{array}$ & $\begin{array}{l}- \\
0.0 \\
746\end{array}$ & 0.0056 & $\begin{array}{l}- \\
0.000 \\
4\end{array}$ \\
\hline $\begin{array}{l}201 \\
2\end{array}$ & $\begin{array}{l}105 \\
.2\end{array}$ & $\begin{array}{l}2.022 \\
0\end{array}$ & $\begin{array}{l}- \\
0.1 \\
289\end{array}$ & 0.0166 & $\begin{array}{l}- \\
0.002 \\
1\end{array}$ \\
\hline $\begin{array}{l}201 \\
3\end{array}$ & $\begin{array}{l}193 \\
.4\end{array}$ & $\begin{array}{l}2.286 \\
5\end{array}$ & $\begin{array}{l}0.1 \\
356\end{array}$ & 0.0184 & $\begin{array}{l}0.002 \\
5\end{array}$ \\
\hline $\begin{array}{l}201 \\
4\end{array}$ & $\begin{array}{l}147 \\
.9\end{array}$ & $\begin{array}{l}2.170 \\
0\end{array}$ & $\begin{array}{l}0.0 \\
191\end{array}$ & 0.0004 & $\begin{array}{l}0.000 \\
0\end{array}$ \\
\hline $\begin{array}{l}201 \\
5\end{array}$ & $\begin{array}{l}277 \\
.5\end{array}$ & $\begin{array}{l}2.443 \\
3\end{array}$ & $\begin{array}{l}0.2 \\
924\end{array}$ & 0.0855 & $\begin{array}{l}0.025 \\
0\end{array}$ \\
\hline $\begin{array}{l}201 \\
6\end{array}$ & $\begin{array}{l}124 \\
.5\end{array}$ & $\begin{array}{l}2.095 \\
2\end{array}$ & $\begin{array}{l}- \\
0.0 \\
557\end{array}$ & 0.0031 & $\begin{array}{l}- \\
0.000 \\
2\end{array}$ \\
\hline $\begin{array}{l}201 \\
7\end{array}$ & $\begin{array}{l}179 \\
.7\end{array}$ & $\begin{array}{l}2.254 \\
5\end{array}$ & $\begin{array}{l}0.1 \\
037\end{array}$ & 0.0107 & $\begin{array}{l}0.001 \\
1\end{array}$ \\
\hline
\end{tabular}

\begin{tabular}{|c|c|c|c|c|c|}
\hline $\begin{array}{c}\text { Tah } \\
\text { un }\end{array}$ & $X i$ & $\begin{array}{c}\log \\
X i\end{array}$ & $\begin{array}{c}\log \\
X i- \\
\log \\
X\end{array}$ & $\begin{array}{c}(\log X i \\
-\log \\
X)^{2}\end{array}$ & $\begin{array}{c}(\log \\
X i- \\
\log \\
X)^{3}\end{array}$ \\
\hline 201 & 104 & & 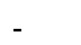 & & - \\
\hline 8 & .6 & $\begin{array}{l}2.019 \\
5\end{array}$ & $\begin{array}{l}0.1 \\
314\end{array}$ & 0.0173 & $\begin{array}{l}0.002 \\
3\end{array}$ \\
\hline 201 & 90. & & - & & - \\
\hline 9 & 5 & $\begin{array}{l}1.956 \\
6\end{array}$ & $\begin{array}{l}0.1 \\
942\end{array}$ & 0.0377 & $\begin{array}{l}0.007 \\
3\end{array}$ \\
\hline 202 & 277 & 2.443 & 0.2 & & 0.025 \\
\hline 0 & .5 & 3 & 924 & 0.0855 & 0 \\
\hline Jum & 378 & 53.77 & & & \\
\hline lah & 4.7 & & 0.0 & & \\
\hline$(\Sigma)$ & & & 0 & 0.63 & 0.01 \\
\hline
\end{tabular}

- $\quad$ Nilai rata-rata $(\bar{X})$

$$
\begin{aligned}
\bar{X} & =\frac{\sum \log \mathrm{Xi}}{\mathrm{n}} \\
& =\frac{53.77}{25}=2.15
\end{aligned}
$$

- $\quad$ Standar deviasi $\left(\mathrm{S}_{\mathrm{x}}\right)$

$$
\begin{aligned}
S_{\mathrm{X}} & =\sqrt{\frac{\sum_{\mathrm{i}=1}^{\mathrm{n}}(\log \mathrm{Xi}-\log \overline{\mathrm{X}})^{2}}{\mathrm{n}-1}} \\
& =\sqrt{\frac{0.63}{24}}=0.16
\end{aligned}
$$

- Koefisien kemiringan $\left(C_{s}\right)$

$$
\begin{aligned}
C_{\mathrm{s}} & =\frac{\mathrm{n} \times \sum_{\mathrm{i}=1}^{\mathrm{n}}(\mathrm{Xi}-\overline{\mathrm{X}})^{3}}{(\mathrm{n}-1) \times(\mathrm{n}-2) \times \mathrm{S}_{\mathrm{x}}{ }^{3}} \\
& =\frac{25 \times 0.01}{24 \times 23 \times(0.16)^{3}}=0.15
\end{aligned}
$$

- $\quad$ Nilai faktor frekuensi $\left(\mathrm{K}_{\mathrm{t}}\right)$

Tabel 7. Nilai Faktor Frekuensi $\left(\mathrm{K}_{\mathrm{t}}\right)$

\begin{tabular}{lll}
\hline $\begin{array}{c}\text { Periode } \\
(\boldsymbol{T})\end{array}$ & \multicolumn{1}{c}{$\boldsymbol{C}_{\boldsymbol{s}}$} & \multicolumn{1}{c}{ Nilai $(\mathrm{KT})$} \\
\hline 2 & 0.1499 & -0.02498 \\
\hline 5 & 0.1499 & 0.833 \\
\hline 10 & 0.1499 & 1.296 \\
\hline 25 & 0.1499 & 1.801 \\
\hline 50 & 0.1499 & 2.133 \\
\hline 100 & 0.1499 & 2.436 \\
\hline 200 & 0.1499 & 2.716 \\
\hline
\end{tabular}

- Curah hujan rencana periode ulang (T) 
Tabel 8. Curah hujan rencana

\begin{tabular}{|c|c|c|c|c|c|}
\hline $\begin{array}{l}\text { Peri } \\
\text { ode } \\
(T)\end{array}$ & $\begin{array}{l}\text { Lo } \\
g \\
X\end{array}$ & $\begin{array}{l}\text { Nilai } \\
(K T)\end{array}$ & $S X$ & $\begin{array}{l}\text { Log } \\
T \\
\text { Tah } \\
\text { un }\end{array}$ & $\begin{array}{l}\text { Anti } \\
\text { log } \\
X t \\
(m \\
m)\end{array}$ \\
\hline 2 & $\begin{array}{l}2 . \\
15\end{array}$ & $\begin{array}{l}- \\
0.0249 \\
77528\end{array}$ & $\begin{array}{l}0 . \\
16\end{array}$ & $\begin{array}{l}2.1 \\
5\end{array}$ & $\begin{array}{l}140 . \\
23\end{array}$ \\
\hline 5 & $\begin{array}{l}2 . \\
15\end{array}$ & $\begin{array}{l}0.8330 \\
08427\end{array}$ & $\begin{array}{l}0 . \\
16\end{array}$ & $\begin{array}{l}2.2 \\
9\end{array}$ & $\begin{array}{l}193 . \\
11\end{array}$ \\
\hline 10 & $\begin{array}{l}2 . \\
15\end{array}$ & $\begin{array}{l}1.2964 \\
87359\end{array}$ & $\begin{array}{l}0 . \\
16\end{array}$ & $\begin{array}{l}2.3 \\
6\end{array}$ & $\begin{array}{l}229 . \\
54\end{array}$ \\
\hline 25 & $\begin{array}{l}2 . \\
15\end{array}$ & $\begin{array}{l}1.8014 \\
53651\end{array}$ & $\begin{array}{l}0 . \\
16\end{array}$ & $\begin{array}{l}2.4 \\
4\end{array}$ & $\begin{array}{l}277 . \\
11\end{array}$ \\
\hline 50 & $\begin{array}{l}2 . \\
15\end{array}$ & $\begin{array}{l}2.1329 \\
26966\end{array}$ & $\begin{array}{l}0 . \\
16\end{array}$ & $\begin{array}{l}2.5 \\
0\end{array}$ & $\begin{array}{l}313 . \\
57\end{array}$ \\
\hline 100 & $\begin{array}{l}2 . \\
15\end{array}$ & $\begin{array}{l}2.4358 \\
98875\end{array}$ & $\begin{array}{l}0 . \\
16\end{array}$ & $\begin{array}{l}2.5 \\
5\end{array}$ & $\begin{array}{l}351 . \\
08\end{array}$ \\
\hline 200 & $\begin{array}{l}2 . \\
15\end{array}$ & $\begin{array}{l}2.7163 \\
69381\end{array}$ & $\begin{array}{l}0 . \\
16\end{array}$ & $\begin{array}{l}2.5 \\
9\end{array}$ & $\begin{array}{l}389 . \\
78\end{array}$ \\
\hline
\end{tabular}

\section{Debit saluran rencana ( $\mathbf{Q}_{\text {hidrologi}}$ )}

a. Koefisien run off

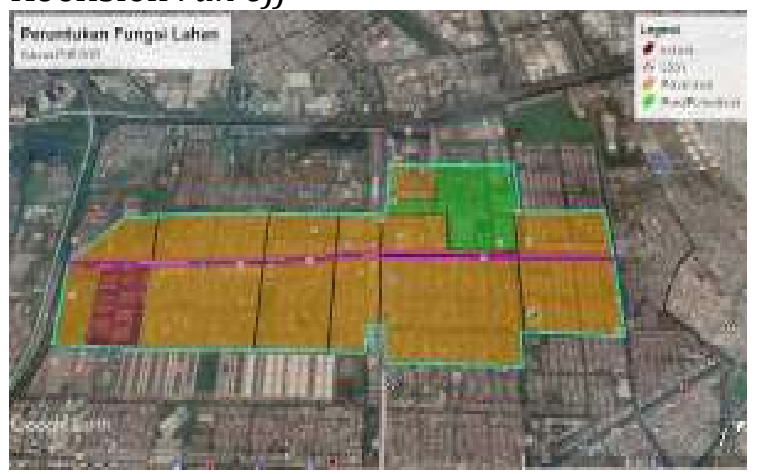

Gambar 3. Peta Tata Guna Lahan
Tabel 9. Nilai Koefisien Run Off

\begin{tabular}{|c|c|c|c|c|c|c|c|}
\hline $\begin{array}{l}\text { Lo } \\
\text { ka } \\
\text { si }\end{array}$ & $\begin{array}{l}\text { Wil } \\
a y \\
a h\end{array}$ & $\begin{array}{l}\text { Lua } \\
\text { S } \\
\text { (A) } \\
\text { km } \\
2\end{array}$ & $\begin{array}{l}\text { Ko } \\
\text { efi } \\
\text { sie } \\
n \\
R u \\
n \\
\text { Off } \\
\text { (c) }\end{array}$ & $\begin{array}{l}\text { Koe } \\
\text { fisie } \\
\text { n } \\
\text { Run } \\
\text { off } \\
\text { Gab } \\
\text { ung } \\
\text { an }\end{array}$ & $\begin{array}{l}( \\
C \\
J \\
r \\
a \\
t \\
a \\
- \\
r \\
a \\
t \\
a\end{array}$ & $\begin{array}{l}L \\
e \\
b \\
a \\
r \\
J \\
a \\
l \\
a \\
n \\
( \\
m \\
J\end{array}$ & $\begin{array}{l}P a \\
\text { nj } \\
\text { an } \\
g \\
\text { Jal } \\
\text { an } \\
(k \\
m \\
)\end{array}$ \\
\hline \multirow{4}{*}{$\begin{array}{c}\text { SA } \\
\text { LU } \\
\text { RA } \\
\text { N } \\
\text { PH } \\
\text { B } \\
\text { BG } \\
\text { R }\end{array}$} & $\begin{array}{l}\text { Ap } \\
\text { art } \\
\text { em } \\
\text { en }\end{array}$ & $\begin{array}{c}0.0 \\
701\end{array}$ & $\begin{array}{c}07 \\
5\end{array}$ & $\begin{array}{l}0.05 \\
257\end{array}$ & $\begin{array}{l}1 \\
. \\
2 \\
1\end{array}$ & $\begin{array}{l}1 \\
3 . \\
5 \\
0\end{array}$ & $\begin{array}{c}0 . \\
84\end{array}$ \\
\hline & $\begin{array}{l}\text { Per } \\
\text { um } \\
\text { aha } \\
\text { n }\end{array}$ & $\begin{array}{c}0.1 \\
2\end{array}$ & $\begin{array}{c}0.7 \\
5\end{array}$ & 0.09 & & & \\
\hline & $\begin{array}{c}\text { Ind } \\
\text { ust } \\
\text { ri }\end{array}$ & $\begin{array}{l}0.1 \\
93\end{array}$ & $\begin{array}{c}0.9 \\
0\end{array}$ & $\begin{array}{c}0.17 \\
37\end{array}$ & & & \\
\hline & $\begin{array}{c}\text { JL. } \\
\text { Ray } \\
\text { a } \\
\text { Ga } \\
\text { din } \\
\text { g } \\
\text { Kir } \\
\text { ana }\end{array}$ & $\begin{array}{c}0.0 \\
113 \\
4\end{array}$ & $\begin{array}{c}0.9 \\
5\end{array}$ & $\begin{array}{c}0.01 \\
077 \\
3\end{array}$ & & & \\
\hline \multirow{4}{*}{$\begin{array}{c}\text { SA } \\
\text { LU } \\
\text { RA } \\
\text { N } \\
\text { PH } \\
\text { B } \\
\text { BG } \\
\text { R }\end{array}$} & $\begin{array}{l}\text { Ap } \\
\text { art } \\
\text { em } \\
\text { en }\end{array}$ & $\begin{array}{c}0.0 \\
416\end{array}$ & $\begin{array}{c}0.7 \\
5\end{array}$ & 2.50 & $\begin{array}{l}1 \\
3 \\
3 \\
0\end{array}$ & $\begin{array}{l}7 . \\
5 \\
2\end{array}$ & $\begin{array}{c}0 . \\
80\end{array}$ \\
\hline & $\begin{array}{c}\text { Per } \\
\text { um } \\
\text { aha } \\
\text { n }\end{array}$ & $\begin{array}{c}0.5 \\
14\end{array}$ & $\begin{array}{c}0.7 \\
5\end{array}$ & 2.55 & & & \\
\hline & $\begin{array}{c}\text { Ind } \\
\text { ust } \\
\text { ri }\end{array}$ & $\begin{array}{c}0.0 \\
878\end{array}$ & $\begin{array}{c}0.9 \\
0\end{array}$ & 2.59 & & & \\
\hline & $\begin{array}{c}\text { JL. } \\
\text { Ga } \\
\text { din } \\
\text { g } \\
\text { Bat } \\
\text { avi }\end{array}$ & $\begin{array}{c}0.0 \\
060 \\
16\end{array}$ & $\begin{array}{c}0.9 \\
5\end{array}$ & & & & \\
\hline
\end{tabular}




\begin{tabular}{cccccccc}
\hline SA & Jl. & 0.0 & 0.9 & 0.03 & 1 & 2 & 1. \\
LU & Bo & 414 & 5 & 940 &. & 1. & 93 \\
RA & ule & 821 & & 807 & 3 & 4 & \\
N & var & 8 & & 1 & 1 & 6 & \\
PH & d & & & & & & \\
B & Bu & & & & & & \\
BG & kit & & & & & & \\
R & Ga & & & & & & \\
& din & & & & & & \\
& g & & & & & & \\
& Ray & & & & & & \\
& a & & & & & & \\
\cline { 2 - 4 } & Jl. & 0.0 & 0.9 & 0.00 & & 1 & 0. \\
& Ke & 073 & 5 & 695 & & 2. & 59 \\
& w & 219 & & 580 & & 4 & \\
& Rec & & & 5 & & 1 & \\
& ide & & & & & & \\
nce & & & & & & \\
\hline
\end{tabular}

Total catchment area $=3.09$

$\mathrm{C}$ rata-rata $=0.78$

b. Kemiringan saluran

Berdasarkan hasil pengukuran Saluran PHB BGR Gading Kirana memiliki panjang 803 meter, elevasi hulu (titik 0) yaitu 2,374 $\mathrm{m}$ dan elevasi hilir (titik 33) yaitu 2,242 meter.

$$
\begin{aligned}
\mathrm{S} & =\frac{\triangle \mathrm{H}}{\mathrm{L}} \\
& =\frac{(2.374-2.242)}{803}=0,0002
\end{aligned}
$$

c. Debit saluran rencana ( $\left.Q_{\text {hidrologi }}\right)$

Tabel 10. Debit Saluran Rencana (Qhidrologi)

\begin{tabular}{llll}
\hline $\begin{array}{l}\text { Period } \\
\text { ulang } \\
(T)\end{array}$ & $\begin{array}{l}\text { Curah } \\
\text { hujan } \\
\text { rencan } \\
\text { a(R) }\end{array}$ & $\begin{array}{l}\text { Waktu } \\
\text { si }(\mathrm{Tc})\end{array}$ & $\begin{array}{l}\text { Intensit } \\
\text { as curah } \\
\text { hujan }\end{array}$ \\
\hline Tahun & $\mathbf{m m}$ & jam & mm/jam \\
\hline 2 & 140.23 & 1.60 & 35.47 \\
\hline 5 & 193.11 & 1.60 & 48.84 \\
\hline 10 & 229.54 & 1.60 & 58.06 \\
\hline 25 & 277.11 & 1.60 & 70.09 \\
\hline 50 & 313.57 & 1.60 & 79.31 \\
\hline 100 & 351.08 & 1.60 & 88.80 \\
\hline 200 & 389.78 & 1.60 & 98.59 \\
\hline
\end{tabular}

\section{Debit saluran eksisting (Qhidrolika) HEC- RAS}

a. Sebelum normalisasi

Tabel 11. Debit Saluran Eksisting

\begin{tabular}{|c|c|c|c|c|c|}
\hline \multirow[t]{2}{*}{$\begin{array}{c}\text { Titi } \\
k\end{array}$} & \multirow[t]{2}{*}{$\begin{array}{l}N \\
o\end{array}$} & $\begin{array}{c}\text { Luas } \\
\text { penam } \\
\text { pang }\end{array}$ & $\begin{array}{c}\text { Kecep } \\
\text { atan } \\
\text { alira } \\
n\end{array}$ & $\begin{array}{c}\text { Debi } \\
t \\
\text { salur } \\
\text { an }\end{array}$ & $\begin{array}{c}\text { Debi } \\
t \\
\text { renc } \\
\text { ana } \\
25 \\
\text { tahu } \\
n\end{array}$ \\
\hline & & $\begin{array}{c}A \\
m^{2}\end{array}$ & $\begin{array}{c}V \\
(m / d \\
e t)\end{array}$ & $\begin{array}{c}Q \\
\text { hidr } \\
\text { olika } \\
\left(\mathrm{m}^{3} /\right. \\
\text { det })\end{array}$ & $\begin{array}{c}Q \\
h i d r \\
\text { ologi } \\
\text { (m/d } \\
\text { et) }\end{array}$ \\
\hline $\begin{array}{l}0+ \\
00\end{array}$ & 0 & 18.63 & 0.779 & $\begin{array}{l}14.5 \\
1\end{array}$ & $\begin{array}{l}\text { Melu } \\
\text { ap }\end{array}$ \\
\hline $\begin{array}{l}0+ \\
02 \\
5\end{array}$ & 1 & 25.31 & 0.835 & $\begin{array}{l}21.1 \\
2\end{array}$ & $\begin{array}{l}\text { Melu } \\
\text { ap }\end{array}$ \\
\hline $\begin{array}{l}0+ \\
05 \\
0\end{array}$ & 2 & 27.87 & 0.853 & $\begin{array}{l}23.7 \\
6\end{array}$ & $\begin{array}{l}\text { Melu } \\
\text { ap }\end{array}$ \\
\hline $\begin{array}{l}0+ \\
07 \\
5\end{array}$ & 3 & 28.45 & 0.863 & $\begin{array}{l}24.5 \\
4\end{array}$ & $\begin{array}{l}\text { Melu } \\
\text { ap }\end{array}$ \\
\hline $\begin{array}{l}0+ \\
10 \\
0\end{array}$ & 4 & 29.89 & 0.877 & $\begin{array}{l}26.2 \\
1\end{array}$ & $\begin{array}{l}\text { Melu } \\
\text { ap }\end{array}$ \\
\hline $\begin{array}{l}0+ \\
12 \\
5\end{array}$ & 5 & 31.50 & 0.895 & $\begin{array}{l}28.1 \\
9\end{array}$ & $\begin{array}{l}\text { Melu } \\
\text { ap }\end{array}$ \\
\hline $\begin{array}{l}0+ \\
15 \\
0\end{array}$ & 6 & 33.56 & 0.918 & $\begin{array}{l}30.8 \\
1\end{array}$ & $\begin{array}{l}\text { Melu } \\
\text { ap }\end{array}$ \\
\hline $\begin{array}{l}0+ \\
17 \\
5\end{array}$ & 7 & 33.08 & 0.920 & $\begin{array}{l}30.4 \\
2\end{array}$ & $\begin{array}{l}\text { Melu } \\
\text { ap }\end{array}$ \\
\hline $\begin{array}{l}0+ \\
20 \\
0\end{array}$ & 8 & 33.46 & 0.928 & $\begin{array}{l}31.0 \\
5\end{array}$ & $\begin{array}{l}\text { Melu } \\
\text { ap }\end{array}$ \\
\hline $\begin{array}{l}0+ \\
22 \\
5\end{array}$ & 9 & 34.00 & 0.936 & $\begin{array}{l}31.8 \\
3\end{array}$ & $\begin{array}{l}\text { Melu } \\
\text { ap }\end{array}$ \\
\hline $\begin{array}{l}0+ \\
25 \\
0\end{array}$ & $\begin{array}{l}1 \\
0\end{array}$ & 33.16 & 0.923 & $\begin{array}{l}30.6 \\
1\end{array}$ & $\begin{array}{l}\text { Melu } \\
\text { ap }\end{array}$ \\
\hline
\end{tabular}
(Qhidrolika) 


\begin{tabular}{|c|c|c|c|c|c|}
\hline \multirow[t]{2}{*}{$\begin{array}{c}\text { Titi } \\
k\end{array}$} & $\begin{array}{l}\boldsymbol{N} \\
\boldsymbol{o}\end{array}$ & $\begin{array}{c}\text { Luas } \\
\text { penam } \\
\text { pang }\end{array}$ & $\begin{array}{c}\text { Kecep } \\
\text { atan } \\
\text { alira } \\
\quad n\end{array}$ & $\begin{array}{c}\text { Debi } \\
\quad t \\
\text { salur } \\
\text { an }\end{array}$ & $\begin{array}{c}\text { Debi } \\
t \\
\text { renc } \\
\text { ana } \\
25 \\
\text { tahu } \\
n\end{array}$ \\
\hline & & $\begin{array}{c}A \\
m^{2}\end{array}$ & $\begin{array}{c}V \\
(m / d \\
e t)\end{array}$ & $\begin{array}{c}Q \\
\text { hidr } \\
\text { olika } \\
\left(m^{3} /\right. \\
\text { det })\end{array}$ & $\begin{array}{c}Q \\
h i d r \\
\text { ologi } \\
(m / d \\
e t)\end{array}$ \\
\hline $\begin{array}{l}0+ \\
27 \\
5\end{array}$ & $\begin{array}{l}1 \\
1\end{array}$ & 32.83 & 0.919 & $\begin{array}{l}30.1 \\
8\end{array}$ & $\begin{array}{l}\text { Melu } \\
\text { ap }\end{array}$ \\
\hline $\begin{array}{l}0+ \\
30 \\
0\end{array}$ & $\begin{array}{l}1 \\
2\end{array}$ & 32.60 & 0.917 & $\begin{array}{l}29.9 \\
1\end{array}$ & $\begin{array}{l}\text { Melu } \\
\text { ap }\end{array}$ \\
\hline $\begin{array}{l}0+ \\
32 \\
5\end{array}$ & $\begin{array}{l}1 \\
3\end{array}$ & 32.82 & 0.929 & $\begin{array}{l}30.4 \\
9\end{array}$ & $\begin{array}{l}\text { Melu } \\
\text { ap }\end{array}$ \\
\hline $\begin{array}{l}0+ \\
35 \\
0\end{array}$ & $\begin{array}{l}1 \\
4\end{array}$ & 31.45 & 0.900 & $\begin{array}{l}28.3 \\
1\end{array}$ & $\begin{array}{l}\text { Melu } \\
\text { ap }\end{array}$ \\
\hline $\begin{array}{l}0+ \\
37 \\
5\end{array}$ & $\begin{array}{l}1 \\
5\end{array}$ & 30.76 & 0.890 & $\begin{array}{l}27.3 \\
8\end{array}$ & $\begin{array}{l}\text { Melu } \\
\text { ap }\end{array}$ \\
\hline $\begin{array}{l}0+ \\
40 \\
0\end{array}$ & $\begin{array}{l}1 \\
6\end{array}$ & 30.22 & 0.883 & $\begin{array}{l}26.6 \\
8\end{array}$ & $\begin{array}{l}\text { Melu } \\
\text { ap }\end{array}$ \\
\hline $\begin{array}{l}0+ \\
42 \\
5\end{array}$ & $\begin{array}{l}1 \\
7\end{array}$ & 29.74 & 0.876 & $\begin{array}{l}26.0 \\
4\end{array}$ & $\begin{array}{l}\text { Melu } \\
\text { ap }\end{array}$ \\
\hline $\begin{array}{l}0+ \\
45 \\
0\end{array}$ & $\begin{array}{l}1 \\
8\end{array}$ & 29.23 & 0.870 & $\begin{array}{l}25.4 \\
3\end{array}$ & $\begin{array}{l}\text { Melu } \\
\text { ap }\end{array}$ \\
\hline $\begin{array}{l}0+ \\
47 \\
5\end{array}$ & $\begin{array}{l}1 \\
9\end{array}$ & 28.57 & 0.863 & $\begin{array}{l}24.6 \\
6\end{array}$ & $\begin{array}{l}\text { Melu } \\
\text { ap }\end{array}$ \\
\hline $\begin{array}{l}0+ \\
50 \\
0\end{array}$ & $\begin{array}{l}2 \\
0\end{array}$ & 28.88 & 0.864 & $\begin{array}{l}24.9 \\
5\end{array}$ & $\begin{array}{l}\text { Melu } \\
\text { ap }\end{array}$ \\
\hline $\begin{array}{l}0+ \\
52 \\
5\end{array}$ & $\begin{array}{l}2 \\
1\end{array}$ & 26.75 & 0.838 & $\begin{array}{l}22.4 \\
1\end{array}$ & $\begin{array}{l}\text { Melu } \\
\text { ap }\end{array}$ \\
\hline $\begin{array}{l}0+ \\
55 \\
0\end{array}$ & $\begin{array}{l}2 \\
2\end{array}$ & 28.04 & 0.854 & $\begin{array}{l}23.9 \\
5\end{array}$ & $\begin{array}{l}\text { Melu } \\
\text { ap }\end{array}$ \\
\hline
\end{tabular}

\begin{tabular}{|c|c|c|c|c|c|}
\hline \multirow[t]{2}{*}{$\begin{array}{c}\text { Titi } \\
k\end{array}$} & \multirow[t]{2}{*}{$\begin{array}{l}N \\
o\end{array}$} & $\begin{array}{c}\text { Luas } \\
\text { penam } \\
\text { pang }\end{array}$ & $\begin{array}{c}\text { Kecep } \\
\text { atan } \\
\text { alira } \\
\quad n\end{array}$ & $\begin{array}{c}\text { Debi } \\
t \\
\text { salur } \\
\text { an }\end{array}$ & $\begin{array}{c}\text { Debi } \\
t \\
\text { renc } \\
\text { ana } \\
25 \\
\text { tahu } \\
n \\
\end{array}$ \\
\hline & & $\begin{array}{c}A \\
m^{2}\end{array}$ & $\begin{array}{c}V \\
(m / d \\
e t)\end{array}$ & $\begin{array}{c}Q \\
\text { hidr } \\
\text { olika } \\
\left(m^{3}\right) \\
\text { det })\end{array}$ & $\begin{array}{c}Q \\
\text { hidr } \\
\text { ologi } \\
(m / d \\
\text { et })\end{array}$ \\
\hline $\begin{array}{l}0+ \\
57 \\
5\end{array}$ & $\begin{array}{l}2 \\
3\end{array}$ & 27.65 & 0.846 & $\begin{array}{l}23.3 \\
8\end{array}$ & $\begin{array}{l}\text { Melu } \\
\text { ap }\end{array}$ \\
\hline $\begin{array}{l}0+ \\
62 \\
5\end{array}$ & $\begin{array}{l}2 \\
4\end{array}$ & 35.06 & 0.948 & $\begin{array}{l}33.2 \\
2\end{array}$ & $\begin{array}{l}\text { Melu } \\
\text { ap }\end{array}$ \\
\hline $\begin{array}{l}0+ \\
62 \\
5\end{array}$ & $\begin{array}{l}2 \\
5\end{array}$ & 35.36 & 0.949 & $\begin{array}{l}33.5 \\
5\end{array}$ & $\begin{array}{l}\text { Melu } \\
\text { ap }\end{array}$ \\
\hline $\begin{array}{l}0+ \\
65 \\
0\end{array}$ & $\begin{array}{l}2 \\
6\end{array}$ & 27.85 & 0.845 & $\begin{array}{l}23.5 \\
4\end{array}$ & $\begin{array}{l}\text { Melu } \\
\text { ap }\end{array}$ \\
\hline $\begin{array}{l}0+ \\
67 \\
5\end{array}$ & $\begin{array}{l}2 \\
7\end{array}$ & 27.96 & 0.853 & $\begin{array}{l}23.8 \\
4\end{array}$ & $\begin{array}{l}\text { Melu } \\
\text { ap }\end{array}$ \\
\hline $\begin{array}{l}0+ \\
70 \\
0\end{array}$ & $\begin{array}{l}2 \\
8\end{array}$ & 28.72 & 0.862 & $\begin{array}{l}24.7 \\
6\end{array}$ & $\begin{array}{l}\text { Melu } \\
\text { ap }\end{array}$ \\
\hline $\begin{array}{l}0+ \\
72 \\
5\end{array}$ & $\begin{array}{l}2 \\
9\end{array}$ & 29.16 & 0.901 & $\begin{array}{l}26.2 \\
6\end{array}$ & $\begin{array}{l}\text { Melu } \\
\text { ap }\end{array}$ \\
\hline $\begin{array}{l}0+ \\
75 \\
0\end{array}$ & $\begin{array}{l}3 \\
0\end{array}$ & 29.35 & 0.905 & $\begin{array}{l}26.5 \\
5\end{array}$ & $\begin{array}{l}\text { Melu } \\
\text { ap }\end{array}$ \\
\hline $\begin{array}{l}0+ \\
77 \\
5\end{array}$ & $\begin{array}{l}3 \\
1\end{array}$ & 30.38 & 0.918 & $\begin{array}{l}27.9 \\
0\end{array}$ & $\begin{array}{l}\text { Melu } \\
\text { ap }\end{array}$ \\
\hline $\begin{array}{l}0+ \\
80 \\
0\end{array}$ & $\begin{array}{l}3 \\
2\end{array}$ & 28.95 & 0.902 & $\begin{array}{l}26.1 \\
1\end{array}$ & $\begin{array}{l}\text { Melu } \\
\text { ap }\end{array}$ \\
\hline $\begin{array}{l}0+ \\
80 \\
6\end{array}$ & $\begin{array}{l}3 \\
3\end{array}$ & 29.15 & 0.905 & $\begin{array}{l}26.3 \\
8\end{array}$ & $\begin{array}{l}\text { Melu } \\
\text { ap }\end{array}$ \\
\hline
\end{tabular}

Debit rencana $\mathrm{Qt}\left(\mathrm{Q}_{\text {hidrologi }}\right)=46,95$ $\mathrm{m}^{3} /$ det 


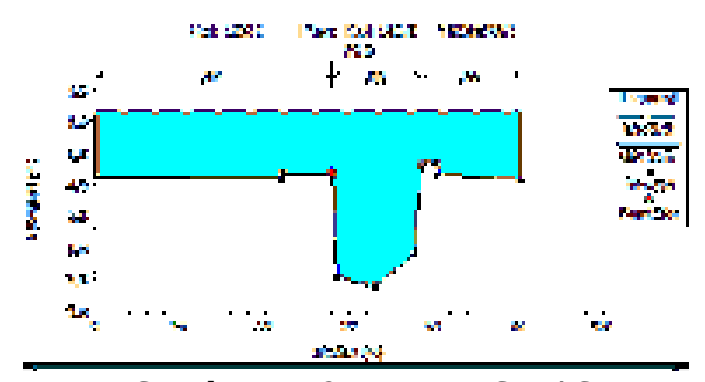

Gambar 4. Output HEC-RAS

Berdasarkan hasil perhitungan aplikasi HEC-RAS, Saluran PHB BGR Gading Kirana tidak dapat menampung debit rencana 25 tahun. Maka Saluran PHB BGR Gading Kirana memerlukan normalisasi.

b. Setelah normalisasi

Tabel 11. Debit Saluran Eksisting (Qhidrolika)

\begin{tabular}{|c|c|c|c|c|}
\hline \multirow[b]{2}{*}{ Titik } & \multirow[b]{2}{*}{$\begin{array}{l}N \\
o\end{array}$} & $\begin{array}{c}\text { Luas } \\
\text { penamp } \\
\text { ang }\end{array}$ & $\begin{array}{c}\text { Kecepat } \\
\text { an } \\
\text { aliran }\end{array}$ & $\begin{array}{c}\text { Debit } \\
\text { rencan } \\
\text { a } 25 \\
\text { tahun }\end{array}$ \\
\hline & & $\begin{array}{c}A \\
\boldsymbol{m}^{2}\end{array}$ & $\begin{array}{c}V \\
(m / d e t)\end{array}$ & $\begin{array}{c}Q \\
\text { hidrol } \\
\text { ogi } \\
(\mathrm{m} / \mathrm{det} \\
\mathrm{J}\end{array}$ \\
\hline $\begin{array}{l}0+0 \\
0\end{array}$ & 0 & 27.44 & 1.710 & $\begin{array}{l}\text { Tidak } \\
\text { Meluap }\end{array}$ \\
\hline $\begin{array}{l}0+0 \\
25\end{array}$ & 1 & 31.77 & 1.480 & $\begin{array}{l}\text { Tidak } \\
\text { Meluap }\end{array}$ \\
\hline $\begin{array}{l}0+0 \\
50\end{array}$ & 2 & 41.3 & 1.140 & $\begin{array}{l}\text { Tidak } \\
\text { Meluap }\end{array}$ \\
\hline $\begin{array}{l}0+0 \\
75\end{array}$ & 3 & 40.87 & 1.150 & $\begin{array}{l}\text { Tidak } \\
\text { Meluap }\end{array}$ \\
\hline $\begin{array}{l}0+1 \\
00\end{array}$ & 4 & 43.16 & 1.090 & $\begin{array}{l}\text { Tidak } \\
\text { Meluap }\end{array}$ \\
\hline $\begin{array}{l}0+1 \\
25\end{array}$ & 5 & 45.56 & 1.030 & $\begin{array}{l}\text { Tidak } \\
\text { Meluap }\end{array}$ \\
\hline $\begin{array}{l}0+1 \\
50\end{array}$ & 6 & 48.28 & 0.970 & $\begin{array}{l}\text { Tidak } \\
\text { Meluap }\end{array}$ \\
\hline $\begin{array}{l}0+1 \\
75\end{array}$ & 7 & 46.96 & 1.000 & $\begin{array}{l}\text { Tidak } \\
\text { Meluap }\end{array}$ \\
\hline $\begin{array}{l}0+2 \\
00\end{array}$ & 8 & 47.1 & 1.000 & $\begin{array}{l}\text { Tidak } \\
\text { Meluap }\end{array}$ \\
\hline $\begin{array}{l}0+2 \\
25\end{array}$ & 9 & 47.57 & 0.990 & $\begin{array}{l}\text { Tidak } \\
\text { Meluap }\end{array}$ \\
\hline
\end{tabular}

\begin{tabular}{|c|c|c|c|c|}
\hline \multirow[b]{2}{*}{ Titik } & \multirow[b]{2}{*}{$\begin{array}{l}N \\
o\end{array}$} & $\begin{array}{c}\text { Luas } \\
\text { penamp } \\
\text { ang }\end{array}$ & $\begin{array}{c}\text { Kecepat } \\
\text { an } \\
\text { aliran }\end{array}$ & $\begin{array}{c}\text { Debit } \\
\text { rencan } \\
\text { a } 25 \\
\text { tahun }\end{array}$ \\
\hline & & $\begin{array}{c}A \\
m^{2}\end{array}$ & $\begin{array}{c}V \\
(m / d e t)\end{array}$ & $\begin{array}{c}Q \\
\text { hidrol } \\
\text { ogi } \\
(\mathrm{m} / \mathrm{det} \\
\mathrm{J}\end{array}$ \\
\hline $0+2$ & 1 & & & Tidak \\
\hline 50 & 0 & 46.75 & 1.000 & Meluap \\
\hline $0+2$ & 1 & & & Tidak \\
\hline 75 & 1 & 46.24 & 1.020 & Meluap \\
\hline $0+3$ & 1 & & & Tidak \\
\hline 00 & 2 & 46.11 & 1.020 & Meluap \\
\hline $0+3$ & 1 & & & Tidak \\
\hline 25 & 3 & 44.97 & 1.040 & Meluap \\
\hline $0+3$ & 1 & & & Tidak \\
\hline 50 & 4 & 44.57 & 1.050 & Meluap \\
\hline $0+3$ & 1 & & & Tidak \\
\hline 75 & 5 & 43.58 & 1.080 & Meluap \\
\hline $0+4$ & 1 & & & Tidak \\
\hline 00 & 6 & 42.85 & 1.100 & Meluap \\
\hline $0+4$ & 1 & & & Tidak \\
\hline 25 & 7 & 42.3 & 1.110 & Meluap \\
\hline $0+4$ & 1 & & & Tidak \\
\hline 50 & 8 & 41.19 & 1.140 & Meluap \\
\hline $0+4$ & 1 & & & Tidak \\
\hline 75 & 9 & 39.46 & 1.190 & Meluap \\
\hline $0+5$ & 2 & & & Tidak \\
\hline 00 & 0 & 40.4 & 1.160 & Meluap \\
\hline $0+5$ & 2 & & & Tidak \\
\hline 25 & 1 & 38.65 & 1.210 & Meluap \\
\hline $0+5$ & 2 & & & Tidak \\
\hline 50 & 2 & 39.72 & 1.180 & Meluap \\
\hline $0+5$ & 2 & & & Tidak \\
\hline 75 & 3 & 39.29 & 1.190 & Meluap \\
\hline $0+6$ & 2 & & & Tidak \\
\hline 25 & 4 & 39.56 & 1.190 & Meluap \\
\hline $0+6$ & 2 & & & Tidak \\
\hline 25 & 5 & 40.1 & 1.170 & Meluap \\
\hline $0+6$ & 2 & & & Tidak \\
\hline 50 & 6 & 38.43 & 1.220 & Meluap \\
\hline $0+6$ & 2 & & & Tidak \\
\hline 75 & 7 & 38.28 & 1.230 & Meluap \\
\hline
\end{tabular}




\begin{tabular}{|c|c|c|c|c|}
\hline \multirow[b]{2}{*}{ Titik } & \multirow[b]{2}{*}{$\begin{array}{l}N \\
o\end{array}$} & $\begin{array}{c}\text { Luas } \\
\text { penamp } \\
\text { ang }\end{array}$ & $\begin{array}{c}\text { Kecepat } \\
\text { an } \\
\text { aliran }\end{array}$ & $\begin{array}{c}\text { Debit } \\
\text { rencan } \\
\text { a } 25 \\
\text { tahun }\end{array}$ \\
\hline & & $\begin{array}{c}A \\
m^{2}\end{array}$ & $\begin{array}{c}V \\
(m / d e t)\end{array}$ & $\begin{array}{c}Q \\
\text { hidrol } \\
\text { ogi } \\
\text { (m/det } \\
\text { ) }\end{array}$ \\
\hline $0+7$ & 2 & & & Tidak \\
\hline 00 & 8 & 39.28 & 1.200 & Meluap \\
\hline $0+7$ & 2 & & & Tidak \\
\hline 25 & 9 & 40.49 & 1.160 & Meluap \\
\hline $0+7$ & 3 & & & Tidak \\
\hline 50 & 0 & 40.6 & 1.160 & Meluap \\
\hline $0+7$ & 3 & & & Tidak \\
\hline 75 & 1 & 41.56 & 1.130 & Meluap \\
\hline $0+8$ & 3 & & & Tidak \\
\hline 00 & 2 & 40.03 & 1.170 & Meluap \\
\hline $0+8$ & 3 & & & Tidak \\
\hline 06 & 3 & 40.18 & 1.170 & Meluap \\
\hline
\end{tabular}

Debit rencana Qt $\left(\mathrm{Q}_{\text {hidrologi }}\right)=46,95$ $\mathrm{m}^{3} /$ det.

\section{KESIMPULAN}

Berdasarkan hasil analisis data diperoleh beberapa kesimpulan antara lain:

1. Debit saluran rencana (Qhidrologi) kali S Debit saluran rencana (Qhidrologi) Saluran PHB BGR melebihi debit saluran eksisting (Qhidrolika) sehingga menyebabkan banjir.

2. Pada analisis data dari titik 0 hingga titik 33, Saluran PHB BGR tidak dapat menampung debit air berdasarkan data curah hujan 25 tahun terakhir sebesar $46,95 \mathrm{~m}^{3} /$ det.

3. Perlu dilakukan normalisasi Saluran PHB BGR dengan dibersihkan dari sedimentasi dan sesuai dimensi awal.

Diperlukan pompa untuk mengalirkan air Saluran PHB BGR ke Kali Sunter sebesar 2 $\mathrm{m}^{3} / \operatorname{det}$ ( 2 buah pompa dengan kapasitas 10 $\mathrm{m}^{3} /$ det).

\section{DAFTAR PUSTAKA}

[1] Arsyad, S. (2006). Konservasi Tanah dan Air. Bogor. IPB Press.

[2] Farizi. D. (2015). Analisis dan Evaluasi Saluran Drainase Pada Kawasan Perumnas Talang Kelapa di Subdas Lambidaro Kota Palembang. Universitas Sriwijaya.

[3] Hardiharjaja. (1997). Irigasi dan Bangunan Air. Jakarta. Gunadarma

[4] Hardiyatmo, H.C. (2008). Teknik Fondasi 2. Yogyakarta: Beta Offset.

[5] Hindarko, S. (2000). Drainase Perkotaan. Edisi Kedua. Penerbit ITB. Bandung.

[6] Jayadi, R. (2000). Pengantar Hidrologi. Universitas Gajah Mada.

[7] Peraturan Menteri Pekerjaan Umum. (2014). Permen. PU No. 12 Tahun 2014 tentang Penyelenggaraan Sistem Drainase Perkotaan. Jakarta

[8] SNI 03-2415-2016. (2016). Tata Cara Perhitungan Debit Banjir Rencana. Jakarta

[9] Soemarto, CD. (1987). Hidrologi Teknik. Penerbit Erlangga. Jakarta

[10] Soeyono, S. (2003). Hidrologi Untuk Pengairan. Pradnya Paramita. Jakarta.

[11] Suripin. (2004). Sistem Drainase Perkotaan yang Berkelanjutan. Penerbit Andi. Yogyakarta.

[12] Triatmodjo, B. (2008). Hidrologi Terapan. Yogyakarta: Beta Offset.

[13] Wahyudi, D. (2017). Tugas Akhir Perencanaan Normalisasi Kali Deluwang Bagian Hilir Kabupaten Situbondo. Institut Teknologi Surabaya.

[14] Wesli. (2008). Drainase Perkotaan. Yogyakarta: Graha Ilmu.

[15] Wicaksono, B, dkk. (2010). Analisa Kinerja Sistem Drainase Terhadap Penanggulangan Banjir dan Genangan Berbasis Konservasi Air di Kecamatan Bojonegoro Kabupaten Bojonegoro. Universitas Brawijaya. 
